\title{
Performance of MahilaMandals of Nehru Yuva Kendras in Tumakuru district, India
}

\author{
Sanjay Yadav $^{1}$, V.L. Madhu Prasad ${ }^{2}$ and D.Harshitha ${ }^{3 *}$ \\ ${ }^{1} P G$ Student, Department of Agricultural Extension, University of Agricultural Sciences, \\ Bengaluru -560065, India \\ ${ }^{2}$ Professor and Chief Instructor, Farmers Training Institute, University of Agricultural \\ Sciences, Bengaluru-560065, India \\ ${ }^{3}$ Senior Research Fellow, Farmers Training Institute, University of Agricultural Sciences, \\ Bengaluru-560065, India \\ *Corresponding author
}

\section{Keywords}

Nehru

YuvaKendras,

Performance,Mahila

Mandals,

Problmesand

Suggestions.

\section{Article Info}

Accepted:

05 January 2020

Available Online:

10 February 2020

\section{A B S T R A C T}

The research study was conducted during 2018-19 in purposively selected Tumakuru district of Karnataka. Out of 10 taluks three taluks were selected based on maximum number of members under Nehru Yuva Kendra (NYK) training programmme. Two mahilamandals from each taluk and from each mahilamandal 20 members were randomely selected thus making a total sample of 120.Data were collected and analysed by using appropriate statistical tools. The results of the study revealed that majority of the respondents belonged to very good category of performance in number of meetings conducted, knowledge on MahilaMandals constitutions and bye-laws (100\%),attended inter-state study tours, participation in state and district level Samelanas in every year(85.83\%),number of members ,selection of group leaders, utilization of savings amount(83.33\%), Repayment of loan barrowed(70.83\%), training undergone 70.00 and attendance of members in meetings $(66.66 \%)$.Further, lack of information on different training programmes of NYKs and lack of periodic guidance were the major problems faced by the members of the MahilaMandals. Provide information about different training programmes of NYKs regularly, provide the required inputs/materials to trainees during and after the training on a subsidised rates were the major suggestions expressed by the members. Hence, NYKs may give attention to improve the performance MahilaMandals with more focus on low performance indicators and also by periodic guidance to the members by organizing more training programmes. 


\section{Introduction}

Women in India are influenced by multiple socio-economic and cultural factors. Emancipation of women is a pre-requisite for nation's economic development and social upliftment. Hence, the concept of MahilaMandal gained significance, especially after 1972 when Nehru Yuva Kendra (NYK) started in India and it started experimenting ensuring the participation of members of MahilaMandals.

The MahilaMandal is defined as a voluntary group valuing personal interactions and mutual aid as a means of altering the problems perceived as alterable and personal by most of its participants. These groups are voluntary associations of people formed to attain certain collective goals that could be economic, social or both without any political affiliation. This strategy made a silent revolution in India regarding poverty eradication by empowering the rural women. MahilaMandals are small groups created for the purpose of enabling members to get economic benefit out of mutual help, empowerment of women and provide employment opportunity. The group based-approach not only enables the poor women to accumulate capital by way of small savings but also help them to have access to formal credit facilities with subsidiary occupations with the help of NYKs.

In general, the MahilaMandals created were implemented to reach the rural women effectively, the women in particular and help them to obtain easy access to facilities like savings and credit in the long run in alleviating poverty by empowering them, providing knowledge about the various training programmes organised by NYKs and create the employment opportunities.

MahilaMandal under Nehru Yuva Kendra are uplifting its members by means of providing trainings that will enable them to selfemployment such as tailoring, knitting, dress designing, beautification, candle making, mehandi designing, bags making, pot designing, hand embroidery, machine embroidery, fresh flowers making/ bouquet and computer course etc. The progress of any MahilaMandal depends on the participation of its members in different programmes organised by NYKs and their active involvement in the activities of programs of MahilaMandals and also the activities organized by the other organizations. Performance is the criteria by which the effectiveness of a MahilaMandal is measured.

Further the level of performance of MahilaMandals in relation to its pre-set objectives was studied to see its effectiveness. The underlying intention of the present study was to investigate the performance of MahilaMandals in relation to its objectives and to elicit the Problems faced by members and their suggestions to overcome the problems.

\section{Materials and Methods}

The study was conducted in purposively selected Tumakuru district of Karnataka. Out of 10 taluks, three taluks namely, Tumakuru, Gubbi and Tiptur were selected based on maximum number of MahilaMandals undergone trainings under NYKs.List of MahilaMandals in each taluk were listed. Two mahilamandals from each taluk and from each mahilamandal 20 members were randomely selected thus making a total sample of 120 .

The data were collected by using personal interview method with the help of the structured interview schedule and analysed by using Minitab software and the statistical tools like frequency, percentage, mean and standard deviation. 


\section{Results and Discussion}

\section{Performance of individual members of MahilaMandals of NYKs}

The data in Table 1 revealed the indicators namely, number of members, selection of group leaders, number of meetings conducted (monthly), attendance of members in meetings, timings of meetings conducted, members savings amount, accumulated savings of MahilaMandals, utilization of savings amount, repayment of loan barrowed, maintenance of books/register's, income generating activities of MahilaMandals, expansion of entrepreneurial skills, knowledge on MahilaMandals constitutions and byelaws (rules and regulations) for conduct of day to day business, knowledge on NYKs programmes, credit facilities availed for selfemployment, attended inter-state study tours, participation in state and district level Samelanas in every year, training undergone, Incentives awards to MahilaMandals.

With regard to number of members, 83.33 per cent and 16.67 percent of mahilamandals are belonged to very good and good categories respectively. About 83.33 per cent and 16.67 percent of MahilaMandals belonged to very good and good categories respectively in selection of group leaders. Cent per cent of MahilaMandals were belonged to very good category respectively in number ( 2 or more meetings in a month) of meetings conducted. Cent per cent of mahilamandals are belonged to very good category in timings of meeting conducted.

Majority (66.66\%) of mahilamandals belonged to low category followed by high and medium $(16.67 \%)$ categories in members saving amount. Further, 53.33 per cent of mahilamandals belonged to low category followed by high $(26.67 \%)$ and medium $(20.00 \%)$ in accumulated savings of mahilamandals. About 83.33 per cent and 16.67 percent of mahilamandals belonged to very good and good categories respectively in utilization of saving amount. About 70.83 per cent, 26.67 per cent and 2.50 per cent of mahilamandals belonged to very good, good and unsatisfactory categories, respectively in repayment of loan barrowed. Majority (66.6\%) of mahilamandals belonged to good category followed by very good $(16.67 \%)$ and unsatisfactory (16.67\%) categories respectively in maintenance of register's/books.

With respect to income generating activities, 46.67 per cent of mahilamandals belonged to medium level followed by low (28.33\%) and high $(25.00 \%)$ level categories respectively. Similarly with regard to expansion of entrepreneurial skills, 50.00 per cent, 33.33 per cent and 16.67 per cent of mahilamandals belonged to high, low and medium level category. Cent per cent of mahilamandals are belonged to very good category in knowledge on mahilamandals constitutions and bye-laws foe conduct of day to day business. Majority $(92.50 \%)$ of mahilamandals were belonged to medium level of category followed by high (7.50\%) level of categories, respectively in knowledge on NYKs programmes.

About 50.00 per cent, 33.33 per cent and 16.67 per cent of mahilamandals were belonged to medium, low and high level of categories respectively in credit facilities availed for self-employment.

Majority of the respondennts (85.83\%) belonged to very good followed by unsatisfactory $\quad(50.00 \%) \quad$ categories respectively in attending inter-state study tours. Nearly 85.83 per cent of mahilamandals were belonged to very good category followed by unsatisfactory $(5.83 \%)$ categories of participation in state and district level samelanas in every year. 
Table.1 Indicator wise performance of members of MahilaMandals of NYKs ( $\mathrm{n}=120)$

\begin{tabular}{|c|c|c|c|c|}
\hline S.No. & Performance Indicators & Category & Frequency & Per cent \\
\hline \multirow[t]{2}{*}{1} & \multirow[t]{2}{*}{ Number of members } & Very good (15-20) & 100 & 83.33 \\
\hline & & Good (10-15) & 20 & 16.67 \\
\hline \multirow[t]{2}{*}{2} & \multirow[t]{2}{*}{ Selection of group leaders } & Very good & 100 & 83.33 \\
\hline & & Good & 20 & 16.67 \\
\hline 3 & $\begin{array}{l}\text { Number of meetings } \\
\text { conducted(monthly) }\end{array}$ & $\begin{array}{l}\text { Very good ( } 2 \text { and more } \\
\text { meetings in a month) }\end{array}$ & 120 & 100.00 \\
\hline \multirow[t]{2}{*}{4} & \multirow{2}{*}{$\begin{array}{c}\text { Attendance of members in } \\
\text { meetings }\end{array}$} & Very good (>90\%) & 80 & 66.66 \\
\hline & & Good (70\%-90\%) & 40 & 33.34 \\
\hline 5 & $\begin{array}{l}\text { Timings of meetings } \\
\text { conducted }\end{array}$ & $\begin{array}{l}\text { Very good (evening } 4 \\
\text { p.m. after ) }\end{array}$ & 120 & 100.00 \\
\hline \multirow{3}{*}{6} & \multirow{3}{*}{ Members savings amount } & High (Rs.>2177.40) & 20 & 16.67 \\
\hline & & Medium & 20 & 16.67 \\
\hline & & low $($ Rs. $<1289.26)$ & 80 & 66.66 \\
\hline \multirow[t]{3}{*}{7} & \multirow{3}{*}{$\begin{array}{c}\text { Accumulated savings of } \\
\text { MahilaMandals (per month) }\end{array}$} & High $(>1441.93)$ & 32 & 26.67 \\
\hline & & $\begin{array}{c}\text { Medium }(833.75- \\
1441.93)\end{array}$ & 24 & 20.00 \\
\hline & & low (Rs.> 833.75) & 64 & 53.33 \\
\hline \multirow[t]{2}{*}{8} & \multirow[t]{2}{*}{ Utilization of savings amount } & $\begin{array}{l}\text { Very good (Fully used for } \\
\text { loaning purposes } \\
\text { only) }\end{array}$ & 100 & 83.33 \\
\hline & & Good (other purposes) & 20 & 16.67 \\
\hline \multirow{3}{*}{9} & \multirow{3}{*}{ Repayment of loan barrowed } & Very good (regular) & 85 & 70.83 \\
\hline & & Good (Poor) & 32 & 26.67 \\
\hline & & Unsatisfactory (default) & 3 & 2.50 \\
\hline \multirow{3}{*}{10} & \multirow{3}{*}{$\begin{array}{l}\text { Maintenance of } \\
\text { books/registers }\end{array}$} & Very good & 20 & 16.67 \\
\hline & & Good & 80 & 66.66 \\
\hline & & Unsatisfactory & 20 & 16.67 \\
\hline \multirow[t]{3}{*}{11} & \multirow{3}{*}{$\begin{array}{c}\text { Income Generating activities } \\
\text { of Mahila } \\
\text { Mandals }\end{array}$} & High (>Rs. 28,081.54) & 30 & 25.00 \\
\hline & & $\begin{array}{c}\text { Medium (Rs. 17,160.13- } \\
\text { 28,081.54)) }\end{array}$ & 56 & 46.67 \\
\hline & & Low (<Rs. 17,160.13) & 34 & 28.33 \\
\hline
\end{tabular}




\begin{tabular}{|c|c|c|c|c|}
\hline \multirow[t]{3}{*}{12} & \multirow{3}{*}{$\begin{array}{l}\text { Expansion of Entrepreneurial } \\
\text { skills }\end{array}$} & High & 60 & 50.00 \\
\hline & & Medium & 20 & 16.67 \\
\hline & & Low & 40 & 33.33 \\
\hline 13 & $\begin{array}{l}\text { Knowledge on Mahila } \\
\text { Mandals constitutions and } \\
\text { bye-laws (rules and } \\
\text { regulations) for conduct of } \\
\text { day to day business }\end{array}$ & $\begin{array}{l}\text { Very good (Known to } \\
\text { all) }\end{array}$ & 120 & 100.00 \\
\hline \multirow[t]{3}{*}{14} & \multirow{3}{*}{$\begin{array}{c}\text { Knowledge on NYKs } \\
\text { programmes }\end{array}$} & High $(>2.23)$ & 9 & 7.50 \\
\hline & & Medium ( $0.74-2.23)$ & 111 & 92.50 \\
\hline & & Low $(<0.74)$ & 0 & 0 \\
\hline \multirow[t]{3}{*}{15} & \multirow[t]{3}{*}{$\begin{array}{l}\text { Credit Facilities availed for } \\
\text { self-employment }\end{array}$} & High ( 4 and more agency) & 20 & 16.67 \\
\hline & & Medium (2-3 agency) & 60 & 50.00 \\
\hline & & Low (<2 agency) & 40 & 33.33 \\
\hline \multirow[t]{2}{*}{16} & \multirow{2}{*}{$\begin{array}{l}\text { Attended inter-state study } \\
\text { tours }\end{array}$} & Very good (Attended) & 103 & 85.83 \\
\hline & & $\begin{array}{c}\text { Unsatisfactory (not } \\
\text { attended) }\end{array}$ & 17 & 50.00 \\
\hline \multirow[t]{2}{*}{17} & \multirow{2}{*}{$\begin{array}{l}\text { Participation in state and } \\
\text { district level Samelanas in } \\
\text { every year }\end{array}$} & Very good (Attended) & 103 & 85.83 \\
\hline & & $\begin{array}{c}\text { Unsatisfactory (not } \\
\text { attended) }\end{array}$ & 17 & 5.83 \\
\hline \multirow[t]{2}{*}{18} & \multirow[t]{2}{*}{ Training undergone } & Very good (Attended) & 84 & 70.00 \\
\hline & & $\begin{array}{l}\text { Unsatisfactory (not } \\
\text { attended) }\end{array}$ & 36 & 30.00 \\
\hline \multirow[t]{3}{*}{19} & \multirow{3}{*}{$\begin{array}{c}\text { Incentives awards to Mahila } \\
\text { Mandals }\end{array}$} & $\begin{array}{l}\text { High (4 and more training } \\
\text { programmes) }\end{array}$ & 14 & 11.66 \\
\hline & & $\begin{array}{c}\text { Medium (2-3 training } \\
\text { programmes })\end{array}$ & 63 & 52.50 \\
\hline & & $\begin{array}{c}\text { Low }(<2 \text { training } \\
\text { programmes })\end{array}$ & 43 & 35.83 \\
\hline
\end{tabular}

Majority (70.00\%) of the respondents belongedto very good and unsatisfactory categories $(30.00 \%)$, respectively in training undergone.About 52.50 per cent of mahilamandals were belonged to medium level of category followed by low (35.83\%) and high $(11.66 \%)$ level of categories respectively in incentives awards to mahilamandals.
Problems faced by members of MahilaMandals in Nehru Yuva Kendra

The results from table 2 and Fig1 indicated that among all the problems faced by MahilaMandals, lack of information on different training programmes of NYK (Rank I), lack of periodic guidance (Rank II), training programs are not need based training 
Table.2 Problems faced by members of MahilaMandals in Nehru Yuva Kendra $(\mathrm{n}=120)$

\begin{tabular}{|c|c|c|c|}
\hline Sl. No. & Particulars & Mean score & Rank \\
\hline 1 & Lack of information on different training programmes of NYK & 2.50 & I \\
\hline 2 & Lack of periodic guidance & 2.20 & II \\
\hline 3 & Training programs are not based on needs & 2.18 & III \\
\hline 4 & Lack of sufficient equipment and machines in training institute & 2.00 & IV \\
\hline 5 & Insufficient training staff & 1.88 & V \\
\hline 6 & Not able to attend trainings due to household work & 1.74 & VI \\
\hline 7 & $\begin{array}{l}\text { Non co-operation from family members to participate in } \\
\text { NYK programmes }\end{array}$ & 1.71 & VII \\
\hline 8 & Long distance of the NYK institute from the native place & 1.61 & VIII \\
\hline
\end{tabular}

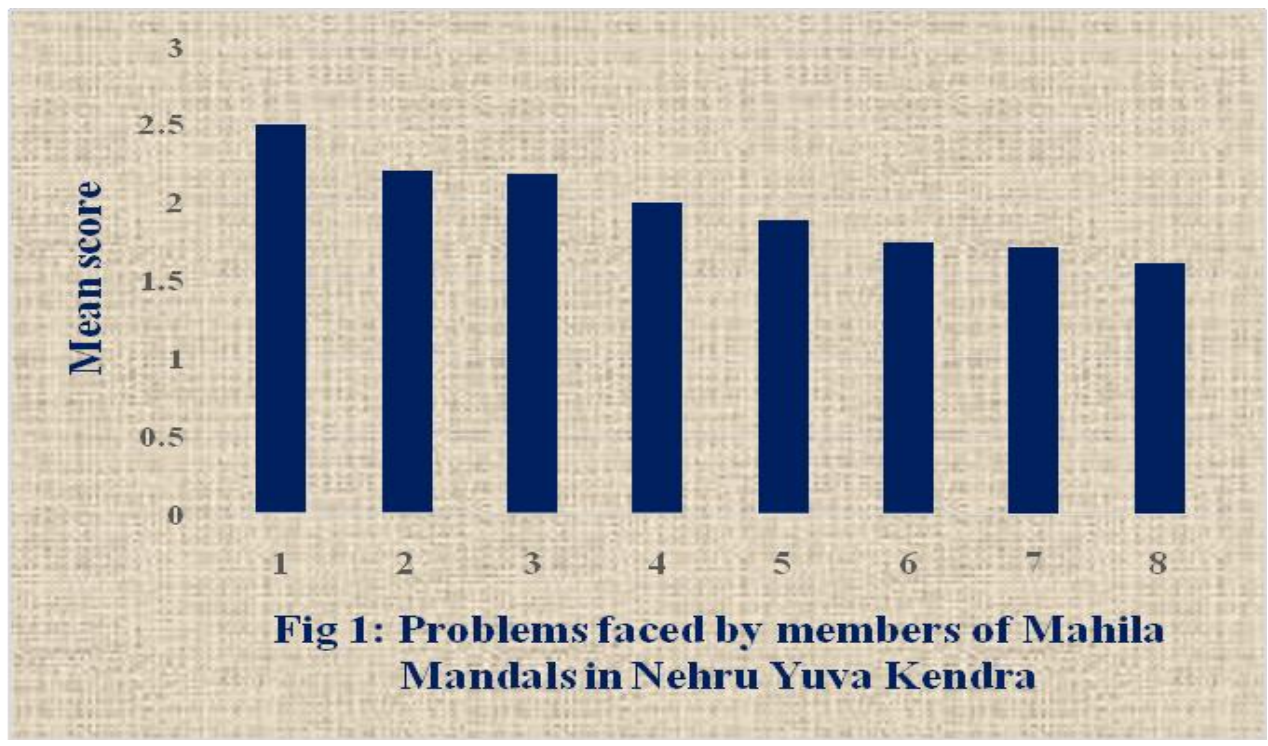

Lack of information on different training programmes of NYK.

Lack of periodic guidance.

Training programs are not based on needs.

Lack of sufficient equipment and machines in training institute.

Insufficient training staff.

Not able to attend trainings due to household work.

Non co-operation from family members to participate in NYK programmes.

Long distance of the NYK institute from the native place

programmes (Rank III) were the major problems faced by MahilaMandals. Further, lack of sufficient equipment and machines in training institute (Rank IV), insufficient training staff (Rank V), not able to attend trainings due to household work (Rank VI), non-cooperation from family members to participate in NYK programmes (Rank VII) and long distance of the NYK institute from the native place (Rank VIII) were relatively 
least problems faced by MahilaMandals. This might be due to NYK focuses mainly on the MahilaMandals in urban areas and nearby places and neglected the MahilaMandals in rural and distant places. These findings are in agreement with findings of Chitra (2011), Sangappa (2012),Vasantha (2014) and Kaur and Karla (2015).

\section{Suggestions to overcome the problems faced by members of MahilaMandals}

A glance at the Table 3 and Fig 2as a whole indicated that among all the suggestions given by members of MahilaMandals, provide information about different training programmes of NYK regularly (Rank I), provide the required inputs/materials to trainees during and after the training on a subsidised rates (Rank II), organise training programmes based on the needs of the MahilaMandal members (Rank III) were the major suggestions given by members of MahilaMandals.

Further, increase the training period from three to six months duration (Rank IV), employ adequate staff to provide training (Rank V),strengthen the follow-up activities (Rank VI), conduct impact/evaluation after the trainings (Rank VII) and establish market linkage to ensure assured income (Rank VIII) were relatively least perceived suggestions given by given by members of MahilaMandals

Table.3 Suggestions to overcome the problems faced by members of MahilaMandals $(\mathrm{n}=120)$

\begin{tabular}{|c|c|c|c|}
\hline Sl. No. & Particulars & Mean & Rank \\
\hline 1 & $\begin{array}{l}\text { Provide information about different training programmes of } \\
\text { NYK regularly }\end{array}$ & 2.67 & I \\
\hline 2 & $\begin{array}{l}\text { Provide the required inputs/materials to trainees during and } \\
\text { after the training on a subsidised rates }\end{array}$ & 2.53 & II \\
\hline 3 & $\begin{array}{l}\text { Organise training programmes based on the needs of the } \\
\text { MahilaMandal members }\end{array}$ & 2.43 & III \\
\hline 4 & Increase the training period from three to six months duration & 2.42 & IV \\
\hline 5 & Employ adequate staff to provide training & 2.20 & V \\
\hline 6 & Strengthen the follow-up activities & 2.17 & VI \\
\hline 7 & Conduct impact/evaluation after the trainings & 2.08 & VII \\
\hline 8 & Establish market linkage to ensure assured income & 1.75 & VIII \\
\hline
\end{tabular}




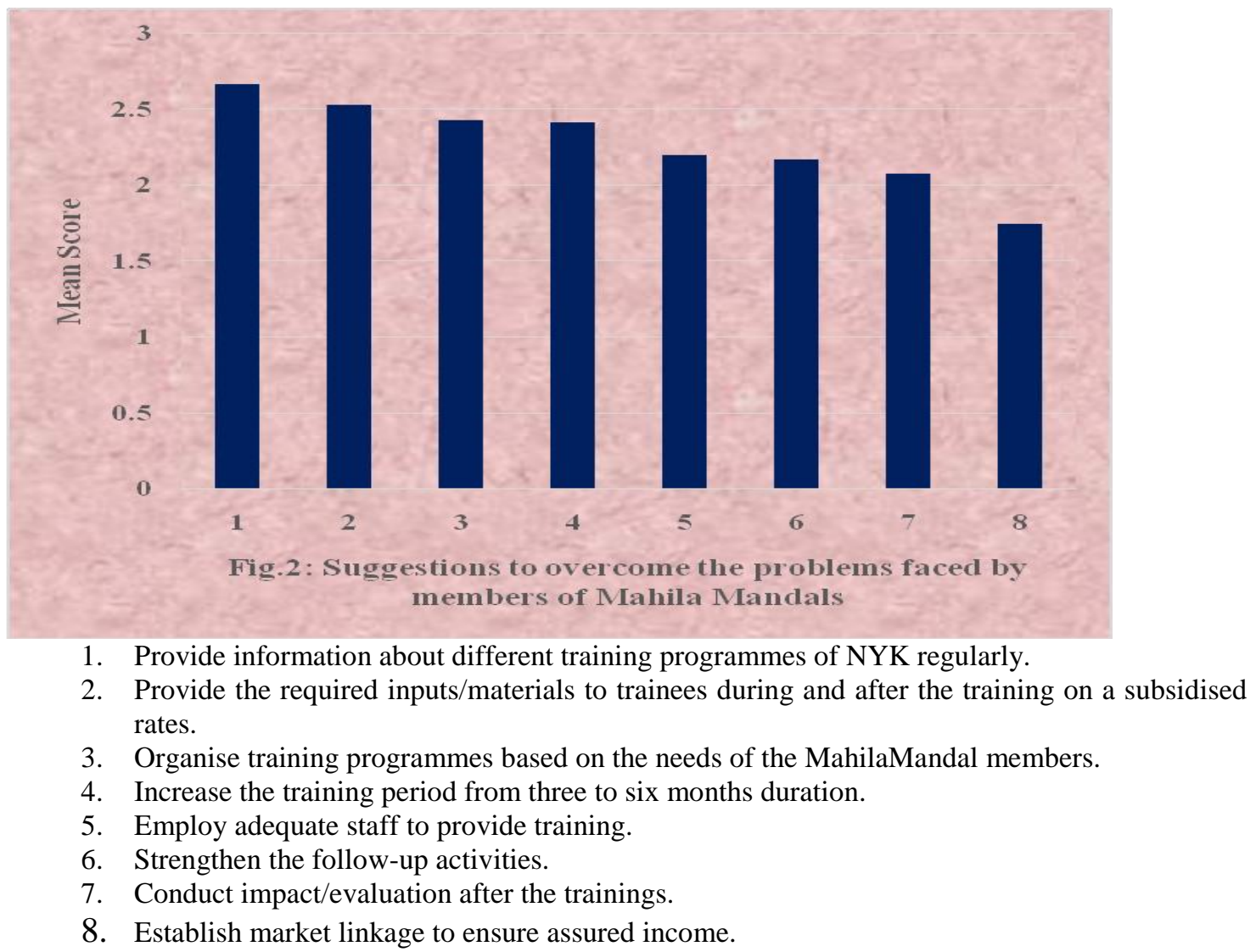

Regularly provide information about different training programmes of NYK was the major suggestion might be due to the fact that they might had less information about different training programmes of NYK.

Hence, there is a need to create an awareness about different training programmes of NYK through different medias. The findings of the study are contrasting with the findings of Josily (2006), Chitra (2011), and Sangappa (2012)

It can be concluded from the study results that,that majority of the respondents belonged belonged to very good category of performance in number of meetings conducted, knowledge on MahilaMandals constitutions and bye-laws,attended inter-state study tours,participation in state and district level Samelanas in every year, number of members, selection of group leaders,utilization of savings amount, Repayment of loan barrowed, training undergone and attendance of members in meetings.

Further,Lack of information on different training programmes of NYKs and lack of periodic guidance were the major problems faced by the respondents. Provide information about different training programmes of NYKs regularly, provide the required inputs/materials to trainees during and after the training on a subsidised rates were the major suggestions expressed by the members.Hence, NYKs may give attention to improve the MahilaMandals performance by considering the limitations of the low performing MahilaMandals. Further provide periodic guidance to the members and organize more training programmes with focus on the suggestions expressed by respondents 


\section{References}

Chitra, N. N., 2011. Impact of 'Kudumbashree' Programme on Rural Women in Kottayam District of Kerala, M.Sc. (Agri.) Thesis, Univ. Agric. Sci., Banglore.

Sangappa, 2012. Performance of Gender Specific Self Help Groups in Bidar district of Karnataka: A comparative analysis. M.Sc. (Agri.) Thesis, Univ. Agri. Sci., Bangalore.

Josil,Y. S., 2006. Empowerment of rural women through microfinance in Dindigul district of Tamil Nadu. M.Sc. (Agri.) Thesis, Univ. Agric. Sci. Dharwad, Karnataka.

Kaur. L. and Kalra, R. K., 2015. Problems of Self Help Group members in Management of Group Activities. J. Agril. Res.,52(3): 101-104.

Vasantha, S., 2014. Challenges of self-help group members towards income generation activity. Internatl. $J$. Accounting and Financial Mangt. Res.4(2): 1-8.

\section{How to cite this article:}

Sanjay Yadav, V.L. Madhu Prasad and D.Harshitha. 2020. Performance of MahilaMandals of Nehru Yuva Kendras in Tumakuru district. Int.J.Curr.Microbiol.App.Sci. 9(02): 31-39. doi: https://doi.org/10.20546/ijcmas.2020.902.006 